Литвиненко, Ніна. «Нові напрацювання у сфері вітчизняної лінгвостилістики. Рецензія на монографію Тєлєжкіної О. О. «ЗВУК-СЛОВО-ТЕКСТ: мова української поезії II половини XX - початку XXI століття». Харків: Майдан, 2020. 370 с.». Лінгвостилістичні студіï, вип. 11, 2019, с. 212-4.

Lytvynenko, Nina. "Critical Review of the 0.0.Tieliezhkina's Monograph "SOUND-WORD-TEXT: the Language of the Ukrainian Poetry of the Second Half of the XX - Early XXI Century". Kharkiv: Maidan, 2020. 370 p.”. Linguostylistic Studies, iss. 11, 2019, pp. 212-4.

\title{
РЕЦЕНЗІї REVIEWS
}

https://doi.org/10.29038/2413-0923-2020-12-212-214

\section{НОВІ НАПРАЦЮВАННЯ У СФЕРІ ВІТЧИЗНЯНОЇ ЛІНГВОСТИЛІСТИКИ. РЕЦЕНЗІЯ НА МОНОГРАФІЮ}

Тєлєжкіна О. О. «ЗВУК-СЛОВО-ТЕКСТ: мова української поезії

II половини XX - початку ХХІ століття». Харків: Майдан, 2020. 370 c.

\section{Ніна Литвиненко}

Національний медичний університет імені О. О. Богомольця, Київ, Україна

\section{CRITICAL REVIEW OF THE}

O.O.Tieliezhkina's Monograph "SOUND-WORD-TEXT: the Language of the Ukrainian Poetry of the Second Half of the XX - early XXI Century". Kharkiv: Maidan, 2020. 370 p.

\section{Nina Lytvynenko}

Bogomolets National Medical University, Kyiv, Ukraine

Монографічне дослідження 0. О. Тєлєжкіної присвячене вивченню важливої й актуальної лінгвістичної проблеми - поетичної мови, зокрема мови української поезії II половини XX - початку XXI століття.

Монографія $\epsilon$ цілісною глибокою роботою, яка маніфестує доцільність і плідність обраної теоретико-методологічної основи, що грунтується на сучасному комплексному підході до вивчення одиниць мови.

Інформативно насичений матеріал монографії демонструє логічну послідовність у розв'язанні окреслених авторкою проблем.

Структура монографії визначається чітко сформульованим вектором дослідження, що поступово реалізується у п'яти розділах.

Так, у першому розділі, присвяченому систематизації теоретичних засад дослідження, 0. О. Тєлєжкіна реалізує спробу проаналізувати проблему утвердження вчення про поетичну мову в зарубіжній i вітчизняній лінгвістиці, а також створює теоретичне підгрунтя для розуміння поетичної мови як системи. Авторка монографії, узагальнюючи погляди вітчизняних мовознавців на поетичну мову як «системне

(с) Литвиненко Н., Східноєвропейський національний університет імені Лесі Українки, 2019.

Це стаття відкритого доступу на умовах СC BY-NC 4.0 
утворення» і визначаючи їі категорійні характеристики, пропонує власне визначення досліджуваного поняття: «поетична мова - це складна функційна система, що грунтується на природній мові, самооновлюється та самовпорядковується під впливом внутрішніх і зовнішніх чинників і транслює естетично насичені смисли». Дослідниця висновує, що поетичній мові як природній відкритій системі притаманні цілісність, емерджентність, структурність, функційність, динамічність і гетерогенність, і доводить, що як концептуальна система, яка транслює естетично значущу інформацію, поетична мова може оприявнюватися у формі поетичного тексту, що становить художню єдність.

У другому розділі О. О. Тєлєжкіна розглядає український поетичний звукопис досліджуваного періоду і констатує, що в аналізованих творах активно вживаються такі засоби фонічної організації віршового текту, як асонанс, алітерація, тавтограма, еквіфонія, метафонія, «звукові» епітети й метафори, прямі й непрямі звуконаслідування, паронімічна атракція. Окрім того, неабияку увагу авторка приділяє звуковим засобам інструментування як елементам мовної гри, що уможливлює пожвавлення віршової оповіді й породження нових смислів. О. О. Тєлєжкіна доходить висновку, що проаналізовані в рецензованій праці засоби звукопису мають потужний звукозображувальний, художньо-виражальний і текстотвірний потенціал, сприяють створенню оригінального ритмо-інтонаційного малюнка й особливої тональності поетичного твору.

У третьому розділі 0.0 . Тєлєжкіна з'ясовує особливості орнаментування поетичної мови розглядуваного періоду лексикограматичними засобами, 3-поміж яких виокремлює фігури додавання (лексико-синтаксичний контактний повтор - анадиплосис, дистантний провтор - просаподосис, нанизування тих самих слів чи їхніх сполук подвоєння; лексико-морфо-синтаксичний повтор - поліптотон; лексикоморфемно-синтаксичний повтор - анномінація) і фігури контрасту (антитеза, акротеза, амфітеза, діатеза, оксиморон). Автор відзначає, що досліджені лексико-синтаксичні засоби оздоблення поетичної мови II половини XX - початку XXI століття відіграють важливу роль у створенні експресії, особливої ритмомелодійної тональності, посиленні смислових акцентів відповідно до творчого задуму митців.

Предметом вивчення четвертого розділу стали фігури додавання (синтаксичного повтору (анафора, епіфора, симплока, епістрофа), гомеотелевт) та фігури переміщення (інверсія, хіазм), які дослідниця виділяє, грунтуючись на тому, що «стилістичні фігури - це особливі побудови, що відхиляються від звичайного синтаксичного типу й дають оригінальну форму для образного вираження думок і посувань людини». Оскільки у вітчизняній лінгвостилістиці гомеотелевту як стилістичній фігурі не була приділена належна увага, авторка подає удокладнені теоретичні дані про цей засіб і наводить його робоче визначення поняття. Окрім того, у розділі запропоноване уточнене бачення різновидів хіазму й інверсії й наведені власні дефініції циз стилістичних засобів. 
На нашу думку, важливим є те, що О. О. Тєлєжкіна грунтовно розглядає такі стилістичні фігури, як анадиплосис, просаподосис, поліптотон, анномінація, гомеотелевт, які дотепер не були проаналізовані у працях вітчизняних дослідників. Окрім того, авторка удокладнює характеристики фігур синтаксичного повтору (анафора, епіфора, симплока, епістрофа) i фігур контрасту, а також розглянутих фоностилістичних засобів.

Уважаємо, що не менш цікавим $\epsilon$ п'ятий розділ монографії, присвячений лексикографічній рецепції поетичної мови II половини XX початку XXI століття. Дослідниця пропонує власну лексикографічну інтерпретацію поетичного словника як окремих митців, таких, як В. Мисик (словник сполучуваності іменників), В. Боровий (частотний словник слововживання), В. Герасим'юк (пропріальна лексика) (за конкретними збірками), Л. Талалай (фітоніми у поетичній мові) і Д. Павличко (поетичний тезаурус) (за всім творчим доробком), так і зведеного, зокрема української поезії 60-х років (словник художньо-виражальних засобів). Цілком погоджуємося з О. О. Тєлєжкіною в тому, що «авторські словники сприятимуть глибшому розумінню поетичної мовотворчості, уможливлять вироблення всебічної й різнопланової оцінки поетичного доробку того чи того автора з позицій лінгвістики, дадуть змогу визначити вагомість внеску поетів у розбудову лексичної, граматичної і стилістичної систем української мови».

Попри високу оцінку рівня наукового викладу та новизни результатів дослідження О. О. Тєлєжкіної, зауважимо, що словникарські розробки, запропоновані авторкою, безперечно, цінні для розвитку авторської лексикографії, однак наведені варіанти побудови словників не вичерпують усі можливості лексикографічного потрактування поетичної мови згадуваного періоду.

Окрім того, суттєвим доповненням до роботи могли б стати додатки «Словник метамови дослідження», «Покажчик імен».

Висловлені міркування не применшують загальнотеоретичної i практичної вартості рецензованого монографічного дослідження.

Робота виконана на високому науково-дослідницькому рівні 3 використанням сучасної методології лінгвістичного аналізу, залученням великого за обсягом ілюстративного матеріалу для підтвердження теоретичних положень.

Матеріал кожного розділу рецензованої монографії відзначається коректністю викладу, логічними зв'язками. Текст чітко структурований, композиційно довершений. Дослідження має виразне прикладне спрямування і тому є багатоплановим щодо перспективи застосування його результатів.

Безумовно, монографія Олесі Олександрівни Тєлєжкіної «ЗВУКСЛОВО-ТЕКСТ: мова української поезії II половини XX - початку XXI століття» $\epsilon$ вагомим словом у вітчизняній лінгвостилістиці й займе достойне місце в українському мовознавстві.

Рецензія надійшла до редколегії 23.01.2020 